\title{
DIFFERENT SHAPES OF THE HUMAN PINEAL GLAND - A STUDY ON 60 AUTOPSY CASES
}

\author{
AFROZ $\mathrm{H}^{1}$, NURUNNABI ASM ${ }^{2}$, RAHMAN M ${ }^{3}$, NAHAR N ${ }^{4}$, ARA $\mathrm{S}^{5}$
}

\begin{abstract}
Context: The pineal gland has been described as an endocrine or neuroendocrine gland; however, its functions in humans are still to be defined. Different shapes of the human pineal gland have been identified. Due to its small size and different shapes recognition of this gland is much critical. Besides, due to its cellularity it may be mistaken for a neoplasm. Hence, a sound knowledge on different shapes of the pineal gland is essential for neurosurgeons, radiologists and pathologists for better diagnosis and management of pineal disorders.

Methods: A descriptive study was done in the Department of Anatomy, Dhaka Medical College, Dhaka, from July 2009 to June 2010, to see the morphological shape of the human pineal gland. The present study was performed on 60 human pineal glands collected from whole human brains of unclaimed dead bodies that were under postmortem examination in the Department of Forensic Medicine, Dhaka Medical College, Dhaka. The pineal gland was collected from the brain by meticulous dissection. Then, the shape of the pineal gland was observed under the magnifying glass.

Results: In the present study, pea-shaped pineal glands were found $60 \%$ in group A, 30\% in group $B, 5 \%$ in both group $C$ and $D$, while pine cone shaped were found $25 \%$ in group $A, 37.5 \%$ in group $B, 25 \%$ in group $C$ and $12.5 \%$ in group $D$. Besides, fusiform shaped glands were found $18.2 \%$ in group $A, 63.6 \%$ in group $B, 9.1 \%$ in both group $C$ and $D$, where as piriform shaped found $66.7 \%$ in group $B$, and $16.7 \%$ in both group $C$ and $D$. Moreover, cone-shaped glands were found $28.6 \%$ in group $B, 57.1 \%$ in group $C$ and $14.3 \%$ in group $D$.
\end{abstract}

Key words: Human pineal gland, Shape of pineal gland, Autopsy.

J Dhaka Med Coll. 2014; 23(2) : 211-214.

\section{Introduction:}

The pineal gland (or pineal body) has been described as an endocrine or neuroendocrine gland; however, its functions in humans are still to be defined ${ }^{1}$. Researchers also stated that the pineal gland is a small endocrine gland in the vertebrate brain. It produces the serotonin derivative melatonin, a hormone that affects the modulation of wake/sleep patterns in the circadian rhythms and seasonal functions ${ }^{2}$. Pineal pathology especially pineal tumours (pineocytomas/ pineoblastomas) may manifest as consequence of their pressure effects and consist of visual disturbances, headache, mental deterioration, and sometimes dementia-like behaviour etc. ${ }^{3}$. One of the important goals of the neurosurgery is recognition of normal pineal structure in the cerebral hemisphere. However, sometimes small tumours, cysts or even brain matter can be mistaken for localization of the pineal gland. Hence, due to its small size and different shapes recognition of this gland is much critical $^{4}$. Besides, due to its cellularity (in relation to the cortex and white matter), it may be mistaken for a neoplasm ${ }^{5}$. It is also important for radiologists and pathologists to differentiate the normal pineal from any neoplastic growth, secondary metastasis, cyst or even aneurysm whenever investigating the diseases of the pineal gland or of any other related structure in the cerabral region ${ }^{5-7}$. Therefore, sound knowledge on different shapes of the pineal gland is essential for

1. Dr. Halima Afroz, Associate Professor, Department of Anatomy, Green Life Medical College, Dhaka.

2. Dr. Abu Sadat Mohammad Nurunnabi, Assistant Professor, Department of Anatomy, OSD, Directorate General of Health Services (DGHS), Dhaka.

3. Dr. Mushfika Rahman, Associate Professor, Department of Anatomy, Dr. Sirajul Islam Medical College, Dhaka.

4. Dr. Nurun Nahar, Associate Professor, Department of Anatomy, Marks Medical College, Dhaka.

5. Prof. Shamim Ara, Professor and Head, Department of Anatomy, Dhaka Medical College, Dhaka.

Correspondence: Dr. Halima Afroz, Associate Professor, Department of Anatomy, Green Life Medical College, Dhaka. 
neurosurgeons, radiologists and pathologists for better diagnosis and management of pineal disorders. The present study was aimed to see the variations in shape of the pineal gland and compare with the previous studies and available text references.

\section{Methods:}

A descriptive study was done in the Department of Anatomy, Dhaka Medical College, Dhaka, from July 2009 to June 2010, to see the morphological shape of the human pineal gland. The present study was performed on 60 human pineal glands collected from whole human brains of unclaimed dead bodies that were under postmortem examination in the Department of Forensic Medicine, Dhaka Medical College, Dhaka. After the legal formalities, whole of the human brain was collected within 24-36 hours of death. During collection of the samples, appropriate age, sex and the cause of death were noted from the morgue's record book. The samples were brought to the Department of Anatomy, Dhaka Medical College, Dhaka. The samples were tagged immediately bearing code numbers for subsequent identification. Soon after collection, each sample was gently washed with tap water on a dissection tray. Blood and blood clots were removed as far as possible.

Preservation of brains: After collection of whole brain, $100 \mathrm{ml}$ of $40 \%$ formaldehyde solution was injected by using a $50 \mathrm{cc}$ syringe into the brain through the surfaces (superolateral and inferior surfaces). Then it was preserved in $40 \%$ formaldehyde solution for 15 days. After 15 days the pineal glands were collected from the preserved brains and the pineal gland fixed in $10 \%$ formol saline solution.

Procedure of collection of pineal gland from preserved brain: After fixation of the whole of the human brain, the pineal gland was collected by the following steps:

At first, the fingers were placed in the medial part of the horizontal fissure of the left half of the cerebellum and it was separated. Thus the total of the superior and parts of the middle and inferior cerebellar peduncles were exposed. The thin layer of the white matter near the posterior border of the cerebellum was picked up by using a blunt forceps. Exposing the superior cerebellar peduncles, the pineal gland was identified in between the depression of the superior colliculi and observed that it was attached to the dorsal surface of the brain, at the junction of the midbrain and the diencephalon and inferior to the splenium of the corpus callosum ${ }^{8}$. An incision of about $1-2 \mathrm{~cm}$ was given through the splenium of the corpus callosum to approach the pineal region. The pineal gland was taken out from the diencephalon with a careful semilunar cut $^{9}$. The pineal gland was cleared up from other tissues. Then, the shape of the pineal gland was observed under the magnifying glass (Fig.1) and noted down.

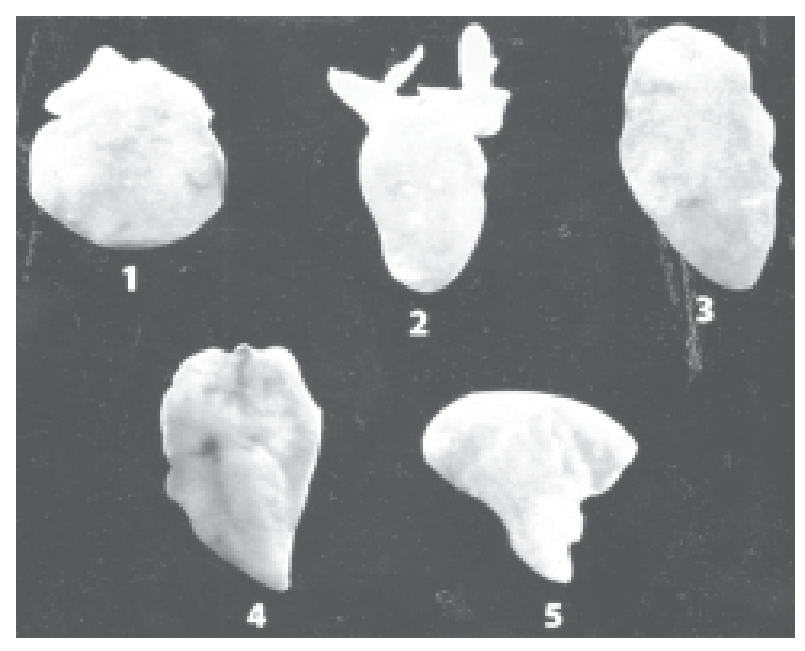

Fig.-1: Different shapes of the pineal gland seen through magnifying glass (1. pea shaped, 2. pinecone shaped, 3. fusiform shaped, 4. cone shaped, 5. piriform shaped).

Common exclusion criteria: i) Decomposed body, ii) any history of injury to the head, iii) any suspected pathology of the pineal gland seen by naked eyes, and iv) if the whole of the pineal gland is not available during dissection.

Grouping of the sample: For convenience, all the samples were categorized in four age-groups including A (15-30 years), B (31-40 years), C (41-50 years) and $\mathrm{D}$ ( $>50$ years), according to Golan et al. (2002) ${ }^{10}$ (Table-I).

Ethical clearance: This study was approved by the Ethical Review Committee of Dhaka Medical College, Dhaka. 


\section{Results:}

In the present study, pea-shaped pineal glands were found $60 \%$ in group A, 30\% in group B, $5 \%$ in both group $\mathrm{C}$ and $\mathrm{D}$, while pine cone shaped were found $25 \%$ in group A, $37.5 \%$ in group B, $25 \%$ in group $\mathrm{C}$ and $12.5 \%$ in group $\mathrm{D}$. Besides, fusiform shaped glands were found $18.2 \%$ in group A, $63.6 \%$ in group B, $9.1 \%$ in both group $\mathrm{C}$ and $\mathrm{D}$, where as piriform shaped found $66.7 \%$ in group $\mathrm{B}$, and $16.7 \%$ in both group $\mathrm{C}$ and $\mathrm{D}$. Moreover, cone-shaped glands were found $28.6 \%$ in group B, $57.1 \%$ in group C and $14.3 \%$ in group D (Table-II, Fig. 2).
Table-I

Grouping of the sample of the present study

$$
(n=60)
$$

\begin{tabular}{llcc}
\hline Group & Age limit & \multicolumn{2}{c}{ Number of samples } \\
& & Male & Female \\
\hline A & 15-30 years & 09 & 09 \\
B & 31-40 years & 17 & 08 \\
C & 41-50 years & 08 & 03 \\
D & $>50$ years & 06 & 00 \\
\hline
\end{tabular}

Table-II

Shape of the pineal gland in different age group

\begin{tabular}{lcccccc}
\hline Age group & $\begin{array}{c}\text { Pea } \\
(\mathrm{n}=20)\end{array}$ & $\begin{array}{c}\text { Pine-cone } \\
(\mathrm{n}=16)\end{array}$ & $\begin{array}{c}\text { Fusiform } \\
(\mathrm{n}=11)\end{array}$ & $\begin{array}{c}\text { Piriform } \\
(\mathrm{n}=6)\end{array}$ & $\begin{array}{c}\text { Cone) } \\
(\mathrm{n}=7\end{array}$ & $\begin{array}{c}\mathrm{P} \\
\text { value }\end{array}$ \\
\hline $\mathrm{A}(\mathrm{n}=18)$ & $12(60 \%)$ & $4(25 \%)$ & $2(18.2 \%)$ & - & - & $<0.05^{*}$ \\
$\mathrm{~B}(\mathrm{n}=25)$ & $6(30 \%)$ & $6(37.5 \%)$ & $7(63.6 \%)$ & $4(66.7 \%)$ & $2(28.6 \%)$ & \\
$\mathrm{C}(\mathrm{n}=11)$ & $1(5 \%)$ & $4(25 \%)$ & $1(9.1 \%)$ & $1(16.7 \%)$ & $4(57.1 \%)$ & \\
$\mathrm{D}(\mathrm{n}=6)$ & $1(5 \%)$ & $2(12.5 \%)$ & $1(9.1 \%)$ & $1(16.7 \%)$ & $1(14.3)$ & \\
\hline
\end{tabular}

Figures in parentheses indicate percentage. Statistical analysis done by Chi-square $\left(\mathrm{c}^{2}\right)$ test, * = significant.

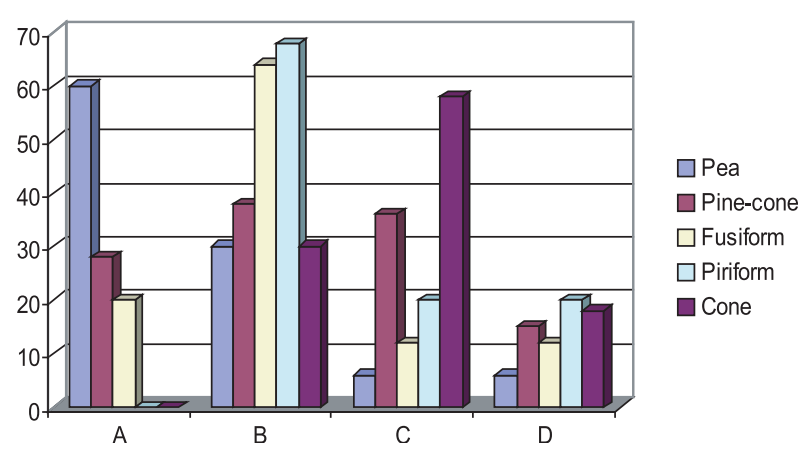

Fig. 2: Shape of the pineal gland in different age group.

\section{Discussion:}

Different shapes of different morphologic characteristics of the pineal gland were found depending on age in the present study. Kelly, Wood \& Enders (1984) ${ }^{11}$ noted the pineal gland as a cone-shaped appendage of the brain. Berkovitz \& Moxham (1988) ${ }^{12}$ stated that the pineal gland is a fusiform organ. According to
Williams et al. (1989) ${ }^{13}$, the pineal gland is a small, piriform, reddish-grey organ. Rogers \& Jacob (1992) ${ }^{14}$ stated that it is a pea-shaped structure. Fawcett (1994) ${ }^{15}$ noted that it is a conical grey body. Reiters $(2001)^{16}$, Docherty $(2007)^{17}$ and Nolte $(2009)^{18}$ found the pineal gland to be a small pine-cone shaped structure. Mescher (2013) ${ }^{19}$ stated that the pineal gland is a flattened conical organ. According to Ross $\&$ Pawlina $(2011)^{1}$ and Gartner \& Hiatt $(2014)^{20}$, the pineal body is a small pine-cone shaped endocrine gland. The results of the present study are more or less similar with the previous studies and text references. Similar studies were done on human parathyroid glands ${ }^{21}$ and adrenal glands ${ }^{22}$ based on autopsy findings in the same teaching institution \& hospital.

\section{Conclusion:}

Age related changes were found in morphological features of pineal gland. In young 
adults, the shape of the pineal gland usually remains pea shaped. With increasing age, it becomes irregular and fusiform, piriform or cone/pine-cone shaped. To the best of our knowledge, this was the first ever experiment done in our country on pineal gland. The results of the present study can be used as a standard reference for the shape of the pineal gland of Bangladeshi people and to determine the abnormal evidences in forensic and pathological cases.

\section{References:}

1. Ross MH, Pawlina W. Histology: a text and atlas with correlated cell and molecular biology. $6^{\text {th }}$ ed. Baltimore: Lippincott Williams \& Wilkins; 2011 : p.752-5.

2. Macchi M, Bruce J. Human pineal physiology and functional significance of melatonin. Front Neuroendocrinol 2004; 25(3-4): 177-95.

3. Hirato J, Nakazato Y. Pathology of pineal region tumors. J Neurooncol 2001; 54(3): 239-49.

4. Erlich SS, Apuzzo ML. The pineal gland: anatomy, physiology, and clinical significance. J Neurosurg 1985; 63(3): 321-41.

5. Kleinschmidt-DeMasters BK, Prayson RA. An algorithmic approach to the brain biopsy - Part I. Arch Pathol Lab Med 2006; 130(11): 1630-8.

6. Todo T, Kondo T, Shinoura N, Yamada R. Large cysts of the pineal gland: report of two cases. Neurosurgery $1991 ; 29(1)$ : 101-5.

7. Gokhale S, Laskowitz DT. Teaching neuroimages: vein of Galen aneurysm mimicking pineal mass in a young adult. Neurology 2013; 80(22): e240.

8. Romanes GJ. ed. Cunningham's manual of practical anatomy. Vol.3. $15^{\text {th }}$ ed. New York: Oxford University Press; 2000: p.244-5.

9. Antiæ S, Javanoviæ I, Stefanoviæ N, Pavloviæ S, Ranèiæ G, Ugrenoviæ S. Morphology and histochemical characteristics human pineal gland acervuli during the aging. Facta Universitatis: Med Biol 2004; 11(2): 63-8.
10. Golan J, Torres K, Staœkiewicz GJ, Opielak G, Maciejewski R. Morphometric parameters of the human pineal gland in relation to age, body weight and height. Folia Morphol 2002; 61(2): 111-3.

11. Kelly DE, Wood RL, Enders AC. eds. Bailey's textbook of microscopic anatomy. $18^{\text {th }}$ ed. Baltimore: Williams \& Wilkins; 1984: p.816-20.

12. Berkovitz BKB, Moxham BJ. A textbook of head and neck anatomy. Chicago: Year Book Medical Publishers; 1988: p.534-5.

13. Williams PL, Warwick R, Dyson M, Bannister LH. eds. Gray's anatomy. $37^{\text {th }}$ ed. Edinburgh: Churchill Livingstone; 1989: p. 1456-9.

14. Rogers AW, Jacob S. Textbook of anatomy. $1^{\text {st }}$ ed. Edinburgh: Churchill Livingstone; 1992: p.320-1.

15. Fawcett DW. Bloom \& Fawcett - a textbook of histology. $12^{\text {th }}$ ed. New York: Chapman \& Hall; 1994: p.516-24.

16. Reiter RJ. Pineal gland. In: Becker KL, Bilezikian JP, Bremner WJ, Hung W, Kahn CR, Loriaux DL, et al. eds. Principles and practice of endocrinology and metabolism. $3^{\text {rd }}$ ed. Philadelphia: Lippincott Williams \& Wilkins; 2001: p.98-102.

17. Docherty B. Endocrine system: part two - the thyroid, pineal and parathyroid gland. Nurs Times 2007; 103(22): 26-7.

18. Nolte J. The human brain: an introduction to its functional anatomy. $6^{\text {th }}$ ed. Philadelphia: Mosby Elsevier; 2009: p.391-3.

19. Mescher AL. ed. Junqueira's basic histology: text and atlas. $13^{\text {th }}$ ed. New York: McGraw-Hill; 2013: p.425-6.

20. Gartner LP, Hiatt JL. Color atlas and text of histology. $6^{\text {th }}$ ed. Baltimore: Lippincott Williams \& Wilkins; 2014: p.248-9.

21. Mahbub S, Ara S, Alim A, Nurunnabi ASM, Ahmed $\mathrm{R}$, Begum M. Different shapes of the human parathyroid glands - a postmortem study. J Dhaka Med Coll 2009; 18(1): 44-6.

22. Siddiqua D, Nurunnabi ASM, Ara S, Perven HA. Cadaveric study of different shapes of the human adrenal glands. J Dhaka Med Coll 2012; 21(2): 140-2. 